\title{
MULHERES EM PROCESSO DE ENVELHECIMENTO E SEUS OBJETOS DE PENTEADEIRA: ESTUDO ETNOGRÁFICO NO VALE DO SINOS/RS
}

\author{
Sandra Maria Costa dos Passos Colling ${ }^{1}$ \\ Ana Luiza Carvalho da Rocha ${ }^{2}$
}

Introdução

O envelhecimento tem sido visto em nossas modernas sociedades contemporâneas com particular atenção, em especial no Brasil. Percebe-se, através dos dados apresentados pelo $\mathrm{IBGE}^{3}$, que o número de idosos vem crescendo no país, nos últimos anos, e onde é possível se constatar que a quantidade de mulheres em processo de envelhecimento é superior a dos homens. No Vale do Sinos/RS, as mulheres acima de 60 anos, na zona urbana, ultrapassam um milhão e meio (IBGE, 2010). E é precisamente o processo de envelhecimento nessa região do estado do Rio Grande do Sul, área de colonização alemã, e com essa população, de que trata o artigo aqui apresentado, oriundo da pesquisa de campo ${ }^{4}$ realizada ao longo dos anos de 2017-18, nas cidades de Portão e Novo Hamburgo.

A disposição em pesquisar sobre a relação de mulheres com seus objetos de penteadeira $^{5}$ tinha por objetivo registrar as suas narrativas acerca de seus processos de envelhecimento, sob a perspectiva dos estudos antropológicos da memória, identidade, gênero e etnia, entre outras. Para a realização do trabalho de campo seguimos as orientações de Foote-Whyte (1975) segundo o qual a rede social de entrada e o modo como se constrói a observação participante com o grupo social pesquisado revelam-se excelentes oportunidades para se refletir acerca dos acontecimentos do cotidiano de nossos parceiros de pesquisa e compartilhar com eles nossas indagações, dúvidas e tomada de decisões durante o processo de investigação. Desse modo, a entrada em

\footnotetext{
${ }^{1}$ Universidade Feevale, Brasil.

${ }^{2}$ Universidade Feevale, Brasil.

${ }^{3}$ Instituto Brasileiro de Geografia e Estatística.

${ }^{4}$ Os dados apresentados ao longo do texto são referentes à pesquisa de campo desenvolvida para a elaboração de dissertação de mestrado em Processos e Manifestações Culturais, com o título "Da caixa de música ao perfume, tudo é tesouro: estudo etnográfico sobre mulheres em processo de envelhecimento e seus objetos de penteadeira, na região do Vale do Rio dos Sinos/RS”.

${ }_{5}^{5}$ Móveis onde se depositam objetos pessoais, normalmente colocadas no quarto, com espelho para que as pessoas possam pentear os cabelos.
} 
campo transcorreu a partir da construção progressiva de uma rede social de oito mulheres em processo de envelhecimento, oriundas de diversas etnias e faixas etárias, mas pertencentes as camadas médias das cidades de Portão e Novo Hamburgo, entre elas a mãe da pesquisadora, Sra Terezinha Laci Costa dos Passos.

O interesse por essa investigação acompanha a presença do objeto penteadeira na trajetória social da própria pesquisadora desde a infância, pois sempre teve esse móvel ao alcance através da linhagem feminina de sua família de origem. Ou seja, por meio dos usos da penteadeira pelas avós paterna e materna e da mãe da pesquisadora. Essa aproximação com o tema dos usos da penteadeira, as questões de gênero e do envelhecimento e o significado dos objetos que ali são dispostos sempre foi, portanto, permeado por uma fascinação pelas memórias que provocam em suas portadoras. Dessa forma, a entrada em campo, a partir de uma observação do familiar (Velho, 1978), da mãe da pesquisadora, Terezinha, explorando sua rede social (Foote-Whyte, 1975) para se chegar às outras interlocutoras.

As trajetórias sociais dessas mulheres retratam algumas convergências na forma como tecem o processo de envelhecimento, mas diferenciam-se na forma como transcorrem as escolhas de seus objetos de penteadeira para tessitura de suas memórias de gênero.

Na conformação da rede social de nossa “informante-chave” podemos constatar uma pluralidade de estilos de vida e visões de mundo configurando as trajetórias sociais de nossas parceiras de pesquisa, com consequências singulares para a forma como elas escolhem seus objetos de penteadeira diante de processos diversos de envelhecimento: algumas mulheres casaram, outras permaneceram solteiras; algumas tiveram filhos, outras não, e outras têm filhos falecidos; algumas adoram viajar, outras preferem ler; umas são católicas, outras luteranas, evangélicas e até mesmo sem confissão religiosa, etc. Da mesma forma, suas idades revelam um largo espectro do processo de envelhecimento: a rede social se compõe de mulheres com idades que variam entre $61 \mathrm{e}$ 102 anos.

Se, por um lado, cada uma delas, no transcurso das suas narrativas biográficas, apresenta suas singularidades, em razão de convergências oriundas da sua condição étnica e de gênero, por outro, em muitos momentos, essas experiências se entrecruzam, pois são parte do tecido histórico e social ao qual pertencem. E é dessa forma, atentando para as especificidades dos jogos das memórias individuais de cada uma e da relação de 
tais jogos com a memória coletiva local, que se pretende abordar o modo como vivem o processo de envelhecimento. Vale destacar, conforme já afirmamos em outras ocasiões que:

[...] as construções destas histórias abarcam caminhos oriundos de diversos lugares, tempos, culturas, etnias, o que abre a possibilidade de se pensar em camadas sociais distintas, com visões a partir de ângulos diferentes e, ao mesmo tempo, em situações comuns vivenciadas por essas mulheres (Colling, 2018: 1070).

Ressaltamos, assim, a importância de se reconhecer, em nossa pesquisa, as diferenças e similitudes entre os processos de envelhecimento de mulheres que vivenciam este momento de suas vidas quando dirigimos nossa atenção aos objetos de suas penteadeiras; recorte que nos permitiu ampliar o campo de investigação em termos do estudo dos jogos de memória a partir dos objetos nos quais as lembranças e reminiscências mais significativas de toda uma vida estão depositados.

As narrativas apresentadas pelas mulheres parceiras da pesquisa sobre sua relação com seus objetos de penteadeira, moradoras das cidades de Portão e Novo Hamburgo, desencadeou uma série de possibilidades de reflexão, sendo uma delas, a questão sobre o envelhecimento. A adesão à perspectiva dos estudos sobre envelhecimento na Antropologia foi fundamental para a pesquisa uma vez que, como afirma Guita Debert (1998):

\begin{abstract}
A antropologia, ao mostrar que a velhice é uma construção social, ao acompanhar sua constituição em problema social e ao discutir os pressupostos que regem o discurso gerontológico, oferece elementos para politização dos debates e da luta envolvida no tratamento do conjunto de questões indissoluvelmente ligados ao envelhecimento (Debert, 1998: 66).
\end{abstract}

Sob esse ponto de vista, seguimos aqui algumas orientações de Ana K. Bassit (2002: 175): “a contribuição que diferentes histórias de vida podem apresentar está pautada no pressuposto de que o envelhecimento é uma experiência diversificada e sujeita às influências de diferentes contextos sociais, históricos e culturais”.

Assim é que, para a execução da pesquisa de campo, optamos pela realização da observação participante, nos moldes clássicos propagados por Foote-White (1975). Um rico processo por meio do qual nos foi possível situar as falas de nossas interlocutoras no contexto das práticas cotidianas expressas no interior de seus lares, onde seus objetos de penteadeira estavam depositados.

Seguindo, portanto, o percursos dos laços sociais entre algumas mulheres tecidas a partir da rede social de Terezinha Laci Costa dos Passos, apresentamos, aqui, 
primeiramente, as parceiras da pesquisa (Imagem 1). Cada uma dessas mulheres conformam os diferentes momentos de vida de Terezinha.

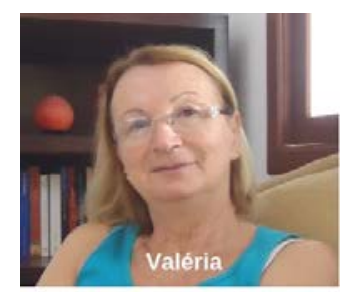

\section{Parceiras de pesquisa}
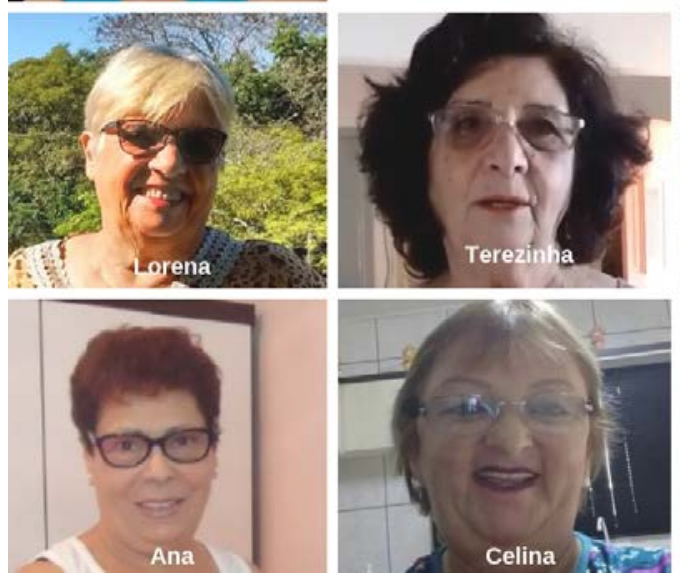

Imagem 1 - Mulheres parceiras de pesquisa.

Fonte: acervo da pesquisadora, 2018.
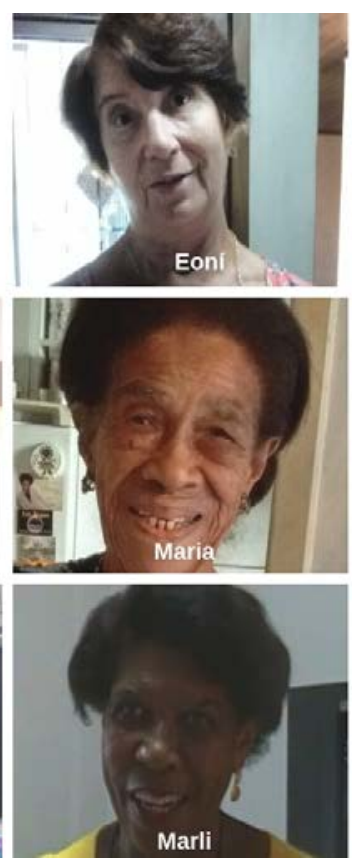

Marli

No processo de envelhecimento dessas mulheres vários acontecimentos ritmaram as suas narrativas biográficas: separações, ameaças de morte, perda de emprego, estudos interrompidos, falecimento dos filhos, cirurgias de alto risco sem nenhuma pessoa para acompanhar ou cuidar. Entretanto, em cada um dos sobressaltos, suas narrativas sempre destacam o esforço na busca por realização pessoal e profissional e o desejo de deixar um legado para seus filhos e netos, afinal, como bem nos lembra Halbwachs (2003),

Nossas lembranças permanecem coletivas e nos são lembradas por outros, ainda que se trate de eventos em que somente nós estivemos envolvidos e objetos que somente nós vimos. Isto acontece porque jamais estamos sós. Não é preciso que outros estejam presentes, materialmente distintos de nós, porque sempre levamos conosco e em nós certa quantidade de pessoas que não se confundem (Halbwach, 2003: 30).

No artigo, além dos registros fotográficos e de diários de campo da pesquisadora, serão apresentados trechos das narrativas das mulheres acerca de seu processo de envelhecimento, bem como uma breve síntese de suas trajetórias sociais. 
Que mulheres são essas?

Terezinha Laci Costa dos Passos nasceu em São Leopoldo no dia 15 de outubro de 1947. Casada, com duas filhas e três netos, reside no município de Portão. Católica, participa ativamente das atividades religiosas dessa comunidade. Aposentada, tendo trabalhado como costureira em fábrica de calçados em Novo Hamburgo e em Portão. Mais tarde foi proprietária de uma lancheria e agora trabalha como recepcionista em um salão de beleza em dias de maior movimento. Começou a dirigir somente depois dos 50 anos de idade e hoje viaja de carro para outros estados e por lugares com trânsito intenso. Para ela, as ocupações de outros espaços fizeram com que ganhasse um novo olhar sobre o mundo e conhecesse pessoas de diferentes idades, padrões sociais, etc. A circulação nestes vários lugares trouxe novas pessoas para seu círculo de amizade e é com esse "circulo de amizades" que passamos a dialogar em nossa pesquisa.

Hoje, Terezinha participa das redes sociais na internet. Está sempre envolvida em atividades esportivas e recreativas em grupos de terceira idade, juntamente com seu esposo. Em suas memórias trata especialmente dos assuntos que envolvem a família. Em suas próprias palavras:

Sou uma mulher que gosta de se sentir livre, independente. Quando quero uma coisa vou lá e tento. Às vezes fico meio pra baixo, mas com o tempo isso passa. Tenho orgulho da minha família e gosto de ajudar as pessoas. Sou também muito religiosa. Além disso, gosto de participar de passeios e de festas, principalmente as que envolvem fantasia (Terezinha, extrato de entrevista, 2017).

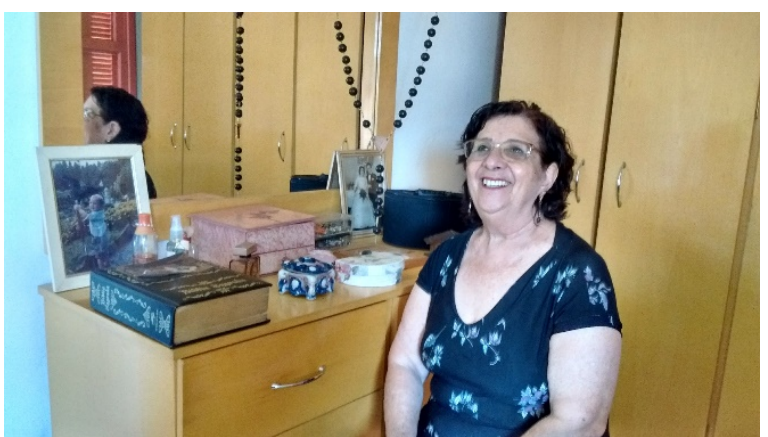

Imagem 2 - Terezinha diante de sua penteadeira. Fonte: acervo da pesquisadora, 2018.

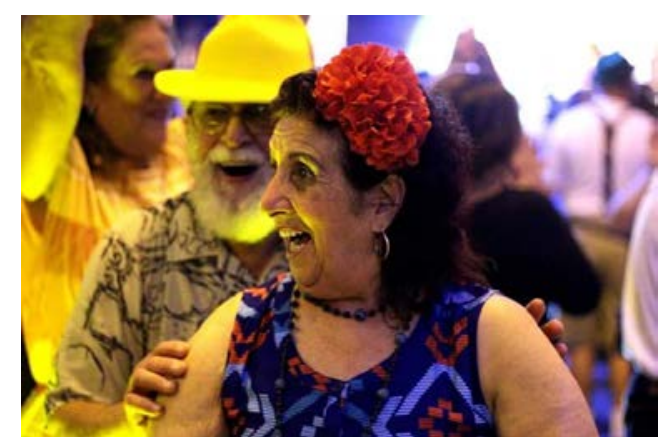

Imagem 3 - Terezinha e o esposo em uma festa. Fonte: acervo pessoal de Terezinha, 2018.

Maria Emília de Mendonça, neta de escravos, nasceu em 14 de junho de 1916, na zona rural de Gravataí. Foi empregada doméstica em residências de famílias tradicionais de Porto Alegre e Novo Hamburgo. Atualmente, viúva, mora em Novo Hamburgo. Ela teve sete filhas. Tem nove netos, doze bisnetos e quatro tataranetos. 
Dona Maria, como é conhecida, tem uma vida cheia de compromissos e é muito requisitada para entrevistas a grandes veículos de comunicação do estado do Rio Grande do Sul. Realiza todas as atividades domésticas e adora receber visitas. Não gosta de assistir televisão, faz caminhadas, viaja frequentemente, vai ao salão de beleza uma vez por semana e lê muito, sem uso de óculos. Adepta da Seicho-no-ie há quase trinta anos, e em suas próprias palavras, é grata pela vida, pela família, pelos amigos e pela alegria de todos os dias:

A gente tem muita fé e com fé se resolve tudo. O que eu peço a Deus, graças ao bom Deus, me vem mesmo. Tenho muito boas filhas e me sinto muito, muito, muito feliz. Eu abro a janela do quarto já agradecendo o céu, a luz, o sol, agradecendo a tudo ela gesticula encena o assunto que está narrando. Tenho muita gratidão a tudo, ao amor, a saúde. A amizade é a maior riqueza que Deus nos deu. Fico muito feliz por essas graças maravilhosas (Maria, extrato de entrevista, 2018).

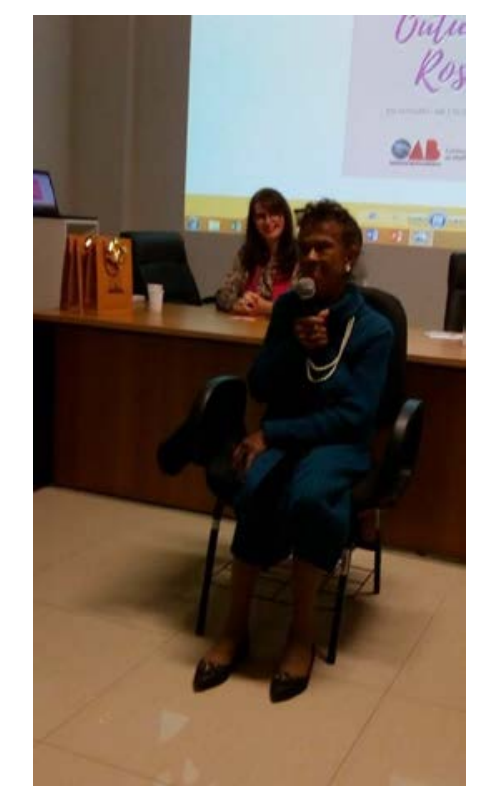

Imagem 4 - Maria em uma palestra. Fonte: acervo da pesquisadora, 2017.

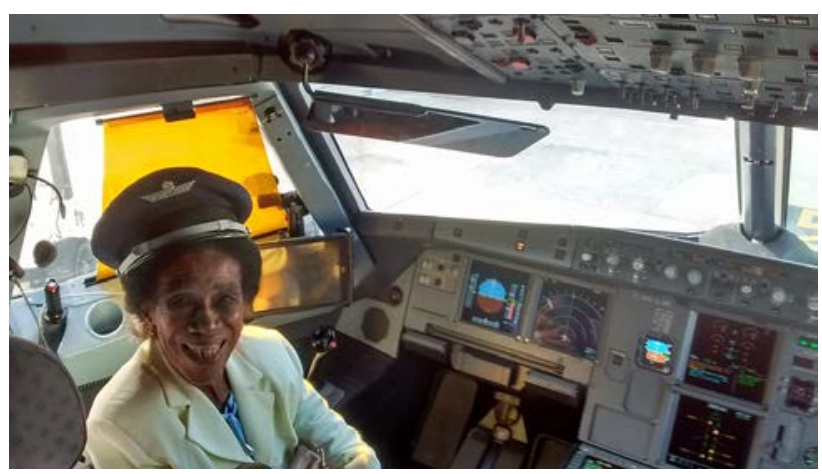

Imagem 5 - Maria na cabine do avião em uma viagem. Fonte: acervo pessoal de Maria, 2018.

Celina de Vargas é uma mulher de origem alemã, com 61 anos, nascida em 27 de dezembro de 1956, na localidade de Linha Temerária, em Nova Petrópolis. Há quase 50 anos é moradora do município de Portão, casada, sendo que teve dois filhos, ambos falecidos. Possui duas netas. Ela foi trabalhadora rural, empregada doméstica, trabalhou em fábrica de calçados e hoje está aposentada. Católica, é membro de um grupo de oração. Gosta muito de viajar e é dona de um abraço inigualável. Participa das redes sociais na internet e, na época da pesquisa, encontrava-se em busca de uma atividade voluntária que pudesse lhe trazer uma ocupação além do serviço em sua casa: 
Eu sou uma mulher de muita batalha. Muita batalha pra conquistar as coisas que a gente sonha, quer. Eu sonho uma coisa e quero conquistar aquilo, sabe? Às vezes eu não consigo, mas a maioria eu consigo, mas batalhando, muito. A gente dá uma caída de vez em quando, mas tem que levantar. É assim que eu me imagino, o que os outros acham eu não sei. Mas isso é o que eu acho (Celina, extrato de entrevista, 2018).

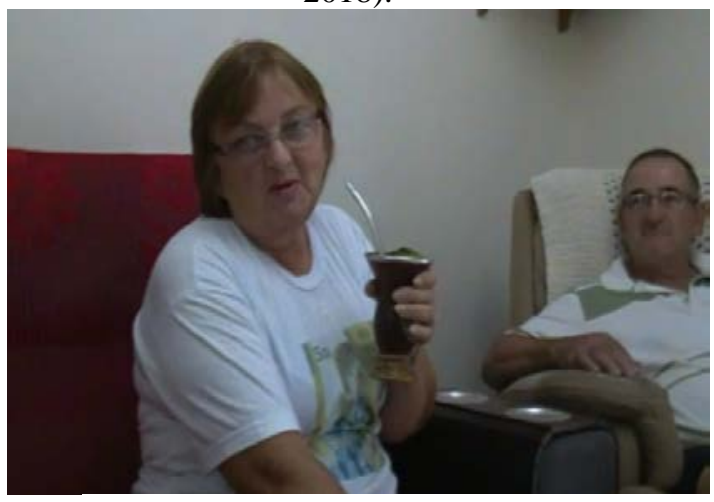

Imagem 6 - Celina e o esposo em sua casa. Fonte: acervo da pesquisadora, 2018.

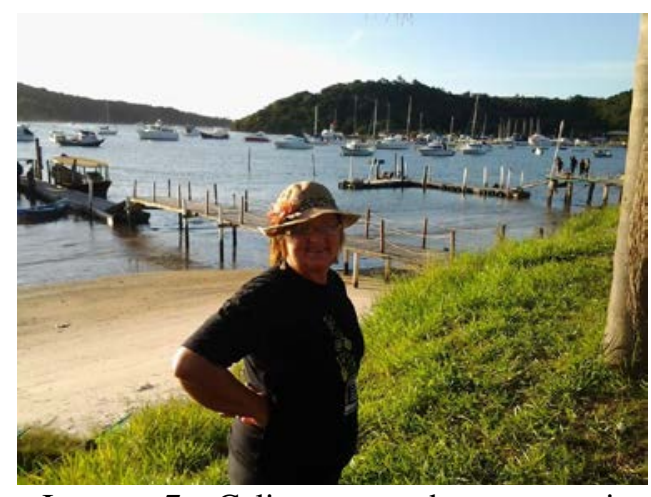

Imagem 7 - Celina em um de seus passeios Fonte: acervo pessoal de Celina, 2018.

Ana Maria Azevedo da Silva nasceu em Capela de Santana no dia 22/04/1946, tendo morado em municípios como São Leopoldo e Estância Velha. Atualmente mora no município de Portão. É casada, aposentada como cabeleireira, tem um casal de filhos, três netos e um bisneto. Católica, participa ativamente da comunidade Nossa Senhora das Graças. Ana Maria é uma mulher vaidosa e demonstra extremo cuidado com as questões que envolvem a saúde e a organização do espaço da casa. Sua fala é doce e mansa, o que altera o ritmo das pessoas que convivem com ela.

Eu me apresento como uma mulher guerreira que eu sempre fui, cuidei sempre dos meus pais, dos meus irmãos, da minha sogra. Cuidei dos meus netos, criei eles até seis, sete anos. Eu acho que eu sou assim, uma pessoa que se dedica às pessoas que precisam. Então eu acho que eu sou guerreira. Eu sempre fui muito doente, eu já fiz várias cirurgias, e foi preciso fazer [...] E eu nunca desanimei, Deus nos dá o que a gente pode aguentar (Ana, extrato de entrevista, 2018).

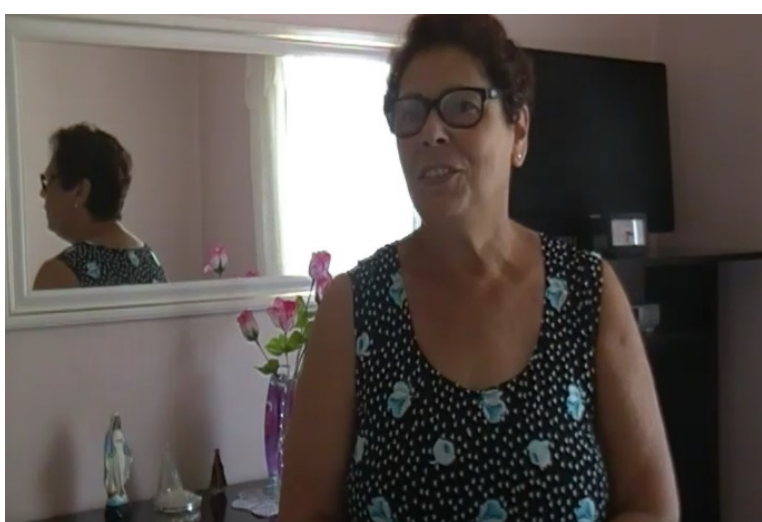

Imagem 8 - Ana diante de sua penteadeira. Fonte: acervo da pesquisadora, 2018.

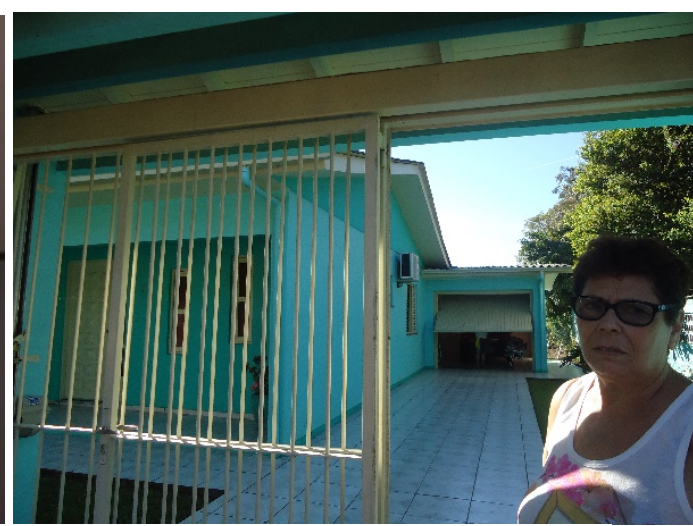

Imagem 9 - Ana em frente a sua casa. Fonte: acervo da pesquisadora, 2018. 
Eoní de Deus da Rosa nasceu no dia 05 de novembro de 1945, embora tenha sido registrada com a data de 10 de novembro, no município de São Leopoldo. Estudou em colégio interno durante muitos anos, se formando professora, profissão que exerceu nas redes públicas estadual e municipal em Portão. Casada, mãe de três filhos, participa do grupo de terceira idade do $\operatorname{Sesc}^{6}$ e de grupos de professoras aposentadas, bem como de grupos sociais pela internet. Sempre se demonstrou uma pessoa encantada por livros, tendo sido bibliotecária por mais de dez anos na maior escola municipal de Portão:

Eu me considero uma professora dona de casa. Eu mantenho esse status de professora. Gosto do grupo de professoras que eu mantenho amizade, a gente se reúne, aqui da antiga Pedro Schüller, a gente mantém um bom relacionamento, é muito bom. Uma professora aposentada, que cuida da casa, gosta do jardim, de viajar, olhar filmes, lê bastante e que gosta de participar desse grupo de amigas que passeia, joga canastra, troca livros e comenta, pra não ficar só aquela dona de casa que fica lavando roupa, louça e se estressando com a casa. Essa sou eu. Uma professora aposentada que procura curtir a vida do melhor jeito que dá porque hoje estamos aqui, amanhã não sabemos. Se a gente for esperar muito para o dia de amanhã não sabe o que pode acontecer (Eoní, extrato de entrevista, 2018).

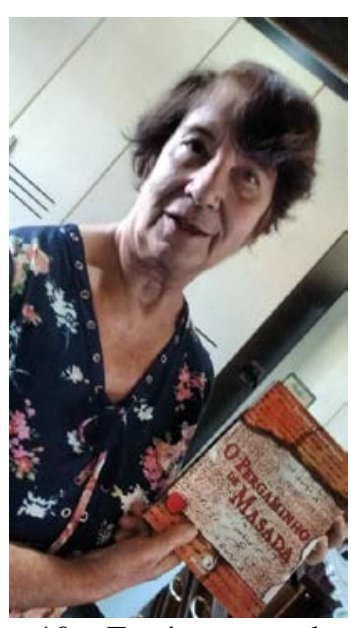

Imagem 10 - Eoní com um de seus livros. Fonte: acervo da pesquisadora, 2018.

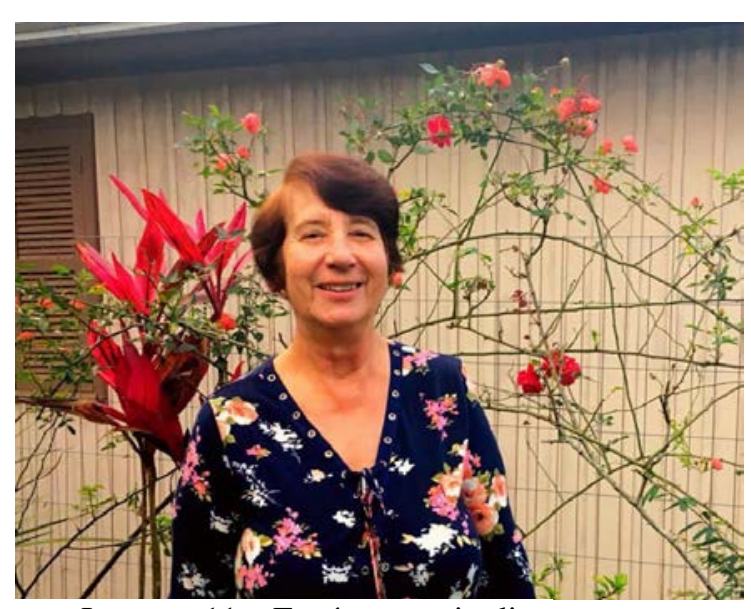

Imagem 11 - Eoní em seu jardim. Fonte: acervo da pesquisadora, 2018.

Lorena da Silva Cunha é nascida em 12 de março de 1939, na localidade de Faxinal que, nessa época, pertencia ao município de São Sebastião do Caí. Descendente de indígenas, portugueses e espanhóis, narra muitas histórias que foram a ela contadas por seus avós. Trabalhou em sua casa quando solteira e, depois de casada, na Prefeitura Municipal de Portão. Mais tarde foi proprietária de uma Papelaria, por muitos anos, tendo encerrado as atividades ao se aposentar. Divorciada, teve três filhas, sete netos e cinco bisnetos. Participa ativamente de grupos como Sesc, Pati $^{7}$ e Clube de Mães,

\footnotetext{
${ }^{6}$ Serviço Social do Comércio.

7 Projeto Amigo da Terceira Idade - projeto coordenado pela Secretaria Municipal de Educação de Portão, que desenvolve atividades físicas, recreativas e culturais para pessoas com idade acima de 60 anos.
} 
fazendo parte da diretoria de todos os grupos. Lorena gosta muito de viajar com grupos ou até mesmo sozinha. É presença marcante nas redes sociais na internet pela forma como se posiciona em diferentes temas. Sua energia é contagiante. Ela nos fala sobre liberdade, sobre as escolhas que pode fazer. Sem compromisso com nada e com ninguém, sente-se "leve”, como ela costuma repetir:

Hoje, aos 79 anos, eu sou uma mulher renovada. Desde que me divorciei, depois dos 60 anos. que minha vida mudou, eu sou uma outra pessoa. Apesar da idade, eu sou uma pessoa que vejo o mundo de um jeito diferente, sou uma pessoa de ideias novas, não sou apegada às coisas antigas, eu acompanho a evolução do mundo. Tenho muito medo das invenções muito modernas, mas temos que aceitar e ir caminhando, junto com o modernismo, com o modo como as coisas são. A Lorena de hoje é uma pessoa prá frente. Pela minha idade não sou uma velha parada no tempo. Eu ando com o giro do mundo (Lorena, extrato de entrevista, 2018).

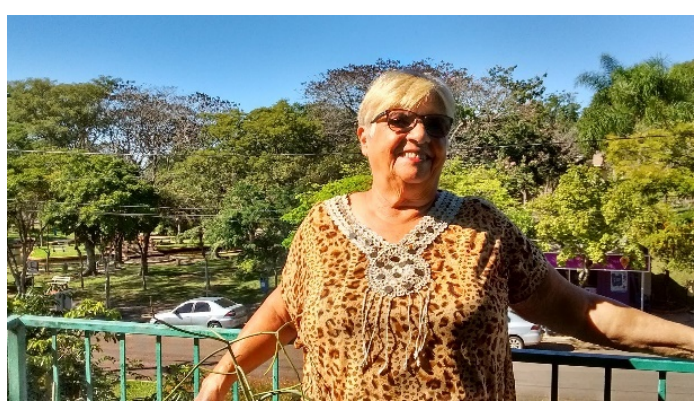

Imagem 12 - Lorena em seu apartamento. Fonte: acervo da pesquisadora, 2018.

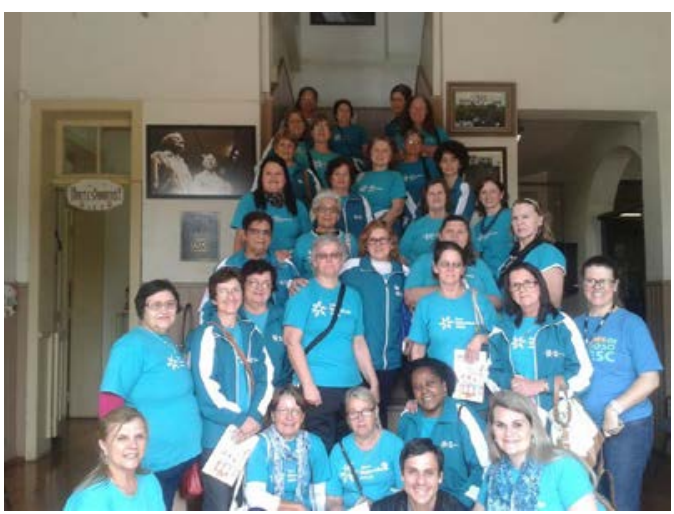

Imagem 13 - Lorena com o grupo do Sesc. Fonte: acervo pessoal de Lorena, 2018.

Marli Helena de Oliveira, nascida no dia 07 de outubro de 1950, em Novo Hamburgo, teve toda sua trajetória de vida desenvolvida neste lugar: estudou, participou de atividades sociais, trabalhou e se aposentou. Trabalhou primeiramente em uma fábrica de calçados e depois, ao cursar Serviço Social, passou a trabalhar na Prefeitura Municipal de Novo Hamburgo tendo coordenado postos de saúde da cidade por vários anos. Divorciada, tem um filho e um casal de netos. É uma das filhas de Maria Emília de Mendonça, também parceira desta pesquisa. Marli adora viajar, acompanhar sua mãe em atividades diversas, cuidar dos netos sempre que necessário e atuar como preletora da Seicho-no-ie. Seu largo sorriso é fácil assim como o de Dona Maria.

Hoje eu me sinto uma mulher forte, que há anos atrás eu não me sentia. Eu acredito que foi pelo que eu passei, pelo que eu vivi. Quando eu ouço, eu leio, que me muitas vezes as dificuldades, elas vêm para nós crescermos, eu acredito nisso. Porque nós temos capacidade infinita como seres humanos, como filhos de Deus e, quando surge uma adversidade, hoje eu tenho força para superar. Então hoje eu me sinto uma mulher forte, uma mulher decidida, uma mulher que sempre procurou cumprir 
com seus deveres, e me considero uma pessoa bem sucedida. Hoje eu me sinto muito feliz (Marli, extrato de entrevista, 2018).

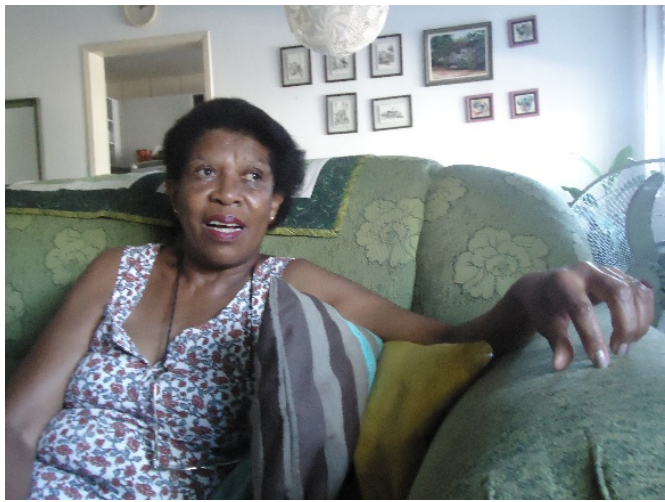

Imagem 14 - Marli em seu apartamento. Fonte: acervo da pesquisadora, 2018.

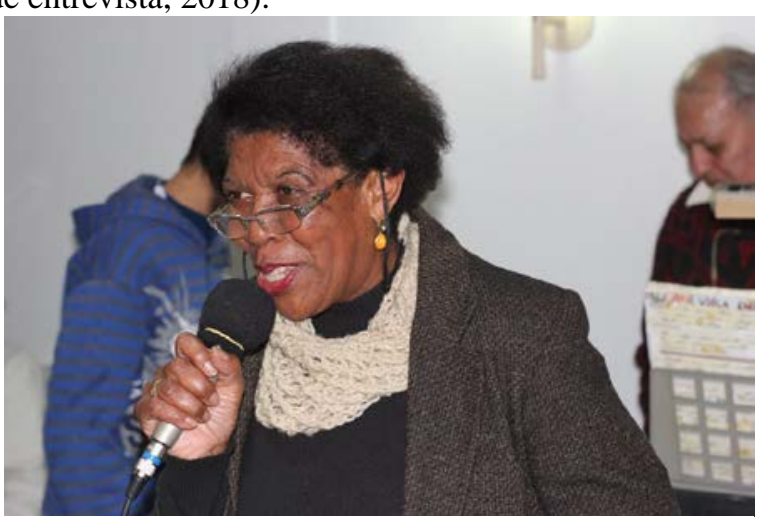

Imagem 15 - Marli discursa no aniversário de Maria. Fonte: acervo pessoal de Marli, 2017.

Valéria Verônica Müller Ely nasceu em 27 de fevereiro de 1949 em São Sebastião do Caí, sendo descendente de alemães. Estudou em colégios internos em Pareci Novo e São Leopoldo quando era criança e mais tarde em escolas nos municípios de Portão e São Leopoldo. Formada em Contabilidade, trabalhou em uma empresa de serviços contábeis, em um banco e em fábricas de calçado, na área de sua formação. Mais tarde foi juíza de pequenas causas, e hoje é aposentada. Em seu segundo casamento, eles adotaram uma menina que afirmam, por todo contexto, ter sido gerada para eles. Valéria participa de grupos de mulheres que realizam atividades diversas e faz curso de trabalhos artesanais variados. Gosta de utilizar as redes sociais da internet para ficar atualizada e rever antigos amigos.

Eu me gosto muito mais hoje do que há anos atrás, até quando eu era mais nova. Eu acho assim, tu dá mais importância a coisas que têm mais essência. Eu me gosto mais assim hoje. Eu vejo assim, que eu valorizo coisas que, quando eu tinha trinta e poucos anos, passava batido. Claro, era da época, aquilo foi importante, eu vivi bem, foi bom. Mas hoje tem mais qualidade, tudo assim, na relação com a família, na relação com os amigos. Acho que vem também daquela coisa assim de tu escolher com quem tu vais dividir as tuas coisas. Eu acho que isso é muito importante. Então, eu me gosto e acho a vida melhor hoje. Eu vou usar uma palavra meia forte, mas eu me sinto plena. Claro, eu tenho sonhos e não poderia deixar de ter porque se tu deixa de sonhar né... eu ainda tenho muita coisa pra fazer e tenho muita coisa pra ver. Eu me defino assim: eu vivo de bem com a vida e com olhos ainda lá no horizonte (Valéria, extrato de entrevista, 2018).

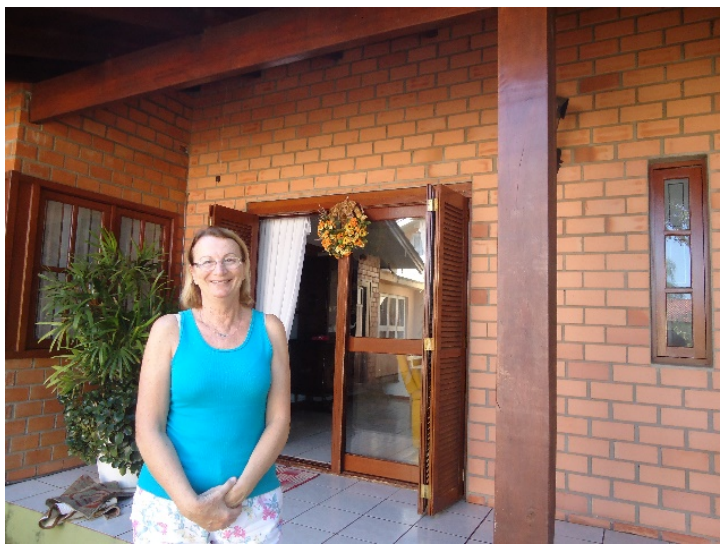

Imagem 16 - Valéria em sua casa.

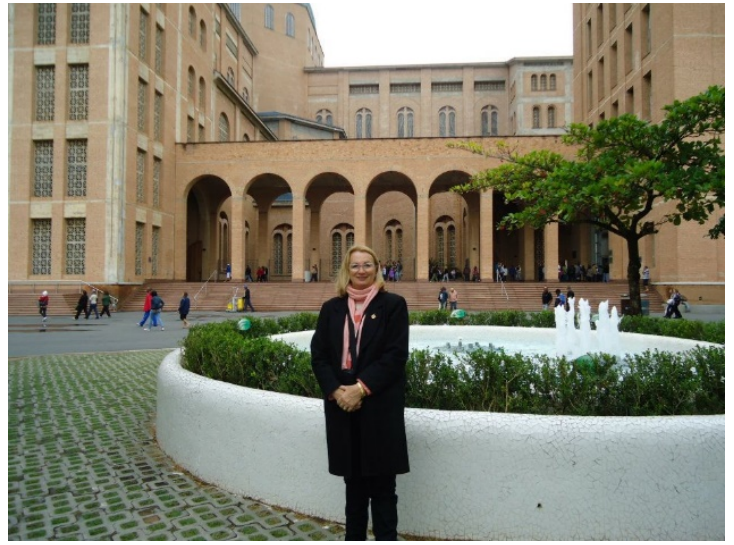

Imagem 17 - Valéria em um de seus passeios. 
Objetos: o que eles contam sobre nós

Como esta investigação trata de objetos e pessoas, do início ao fim, é marcada pela necessidade de movimentos, no tempo e no espaço, num jogo entre sujeito-objeto. Visitar as casas, ver as penteadeiras, captar as imagens das mulheres com os objetos, suas narrativas biográficas e realizar os registros, tudo teve um percurso único, mesmo que houvesse um roteiro pré-estabelecido para tal.

O diário de campo foi companheiro das inúmeras visitas, bem como o gravador e a máquina fotográfica. Ao se observar mulheres e seus objetos guardados, toda forma de registro contribui para as análises posteriores. A etnografia oral e visual traz a narrativa das mulheres diante de seus objetos. Objetos estes que fazem parte da cultura material dessas mulheres e que, nessa pesquisa, foram acompanhados dos estudos de José Reginaldo Gonçalves (2007) com as teorias antropológicas sobre os objetos e os espaços.

Sobre a penteadeira, este móvel surgiu no século $\mathrm{XV}$, período em que o homem era considerado o centro das atenções filosóficas (Branco, 2017). Obviamente, isto remete a questões como a observação de si, cuidados com a aparência, produtos para beleza, ostentação, o que, com o tempo, se tornou popular pelo que o móvel representava, estando associado ao feminino. Acham-se tipos diversos e, inclusive, recebem nomes diferentes para cada estilo. Existem épocas em que móveis e objetos voltam a ter destaque, o que já aconteceu também com a penteadeira. Enfim, são movimentos e transformações ocorridas pelo tempo.

Segundo Fischer (1983: 17) “coisas antigas, aparentemente há muito esquecidas, são preservadas dentro de nós, continuam a agir dentro de nós - frequentemente sem que as percebamos - e de repente vêm à superfície e começam a nos falar”. Inclusive a necessidade interna de pesquisar sobre estes objetos especificamente. A fala das mulheres em processo de envelhecimento 'toca e fala' por e para quem investiga. Com certeza, os guardados vieram à superfície.

Terezinha contou partes de sua história através do relógio de bolso de seu pai. Este objeto está intimamente relacionado à cultura material e traz uma narrativa ligada a sua memória. Neste caso, a memória foi ativada pelo contato com o objeto que estava 
dentro de um porta-joias sobre a penteadeira. O objeto guardado, assim como a história que ela relembrou ao vê-lo novamente:

\begin{abstract}
Meu pai, já doente e envelhecido, me contava histórias que eu adorava. Ele era carreteiro e carregava couro pras fábricas de calçado em Novo Hamburgo, de curtumes daqui, de carreta de boi. Ele tinha carteira de carreteiro, então ele levava horas viajando e tinha esse relógio de bolso que ele carregava junto. Quando ele faleceu, o relógio ficou para mim e carregarei comigo até o fim da minha vida. Depois, será de quem quiser preservar essa lembrança.
\end{abstract}

Esses objetos demonstram a questão da herança geracional da cultura material. Carvalho aborda a questão de que os objetos sempre tiveram uma função social e política, especialmente por afirmar que, para a mulher existia, implicitamente a ideia de que “amar seus objetos é amar a sua família” (Carvalho, 2008: 296). Ademais, muitos outros signos estão impregnados em cada um dos objetos da penteadeira de Terezinha. Inclusive pelo fato de lembrar de lugares, passagens e pessoas que fizeram parte de sua trajetória e que a tornaram a mulher que é hoje, em sua velhice.

Um dos objetos guardados de Dona Maria é uma caixa com versos e poemas de Homero Rosa, de quase 100 anos atrás. E ela declama cada um deles. Esses textos trazem marcas da cidade, de pessoas, de momentos vividos e outros sonhados, como no caso dos que trazem as lembranças de sua mãe que tanto a fizeram chorar:

'Foi tão grande a enchente, que parecia uma revolução, quando se viu o rio foi enchendo, o povo foi alarmando que as Águas de São Miguel já haviam se aproximando. Quando foi no dia dez, as chuvas foram batendo e com o vento do sul, o Rio logo foi enchendo. O rio durou muito tempo, deixando o mundo alagado, foi depois com vento norte que ele foi abaixado.' Tem muitos versos que eu sei decor e mostra o papel dobrado, com alguns pedacinhos puídos, mas com o respeito de quem guarda um documento muito importante, e assim o é para ela. Homero Rosa era escritor e já morreu há muitos anos. Eu sempre, sempre, sempre gostei muito de ler, muito, muito, muito.

Ela traz, em sua narrativa, a cidade de Porto Alegre do início do século passado, com uma doçura que nos faz sentir desejo de ter conhecido esta Porto Alegre a que ela se refere. Mesmo que ela não tenha passado a maior parte de sua vida lá, foi um período muito marcante e, assim, a cidade aparece “como arranjo poético” em sua vida narrada (Eckert e Rocha, 2010: 131).

Marli, entre tantos objetos, nos mostra uma fotografia em que ela, jovem, aparece ao lado de sua irmã no dia em que esta foi coroada Rainha do Esporte Clube Cruzeiro, de Novo Hamburgo, na década de 70: 
Aqui tem a Jaci, minha irmã que já retornou ao mundo espiritual, isso era num baile onde nós estávamos juntas, ela foi Rainha do Clube, a gente sempre fazia as roupas para ir nas festas e bailes. Minha mãe sempre era preocupada da gente estar bem vestida. As fotografias que eu guardo são muito marcantes em minha vida.

Samain (1995) trata sobre o surgimento da antropologia e da fotografia num mesmo período, sendo importante pensar na necessidade que o homem tinha e tem de se ver de outras formas. Assim, através da associação das narrativas e das imagens, tanto anteriores como no momento da etnografia, podemos ver e falar sobre nossas interlocutoras de pesquisa de uma forma mais ampla ao mesmo tempo que mais minuciosa. A antropologia visual nos ajuda a observar de forma mais íntima quem são estas mulheres. Valéria tem guardado um relógio despertador. Na entrevista, ela o pega, dá corda e vai falando:

\begin{abstract}
Esse relógio aqui era do pai - e o relógio começa a tocar uma musiquinha enquanto ela continua - esse relógio aqui era do pai, mas esse relógio só era usado o despertador dele quando a Lúcia (irmã dela) morava no Paraguai. Ela vinha e daí tinha que pegar o avião de madrugada. Então a mãe não gostava dessa música porque lembrava ela de que a Lúcia ia viajar. Ele ficou parado, e não funcionava. E tudo porque ela não queria - daí ela suspira, faz uma pausa e fala como a mãe falava: 'Bota no lixo, isso não me faz bem' e eu disse, ai mãe ele tem um estilo, eu acho. E peguei ele pra mim e ele tá aí, olha quantos anos. A Lúcia tá casada há 35 anos, 36 eu acho. Então eu fiquei com ele e ele tá aí. A mãe não gostava dessa música - e coloca ele no lugar novamente, falando com o objeto: vê se tu pára de tocar - e o relógio continua por um bom tempo tocando a música ainda.
\end{abstract}

Os objetos remontam histórias, ligam pessoas, tempos e lugares. Conforme assinala R. Gonçalves (2007: 114), o objeto que se torna patrimônio "faz a mediação sensível entre seres humanos e divindades, entre mortos e vivos, passado e presente, entre o céu e a terra, entre outras oposições”. Aqui, no caso de Valéria, além do objeto em si, o som que ele produz parece promover esta mediação.

Outra de nossas parceiras de pesquisa, Eoní possui duas penteadeiras, uma ainda de seu tempo de solteira. Ela adora sentar-se diante dela e pensar na vida. Sobre essa penteadeira mais antiga ela tem um objeto ainda mais antigo:

Olha, isso aí é bem antigo, vem passando de geração em geração - é um espelho pequeno num porta espelho. Eu sempre uso ele lá na janela pra tirar os fios do rosto, ele aproxima bem, ele vira. Ele era da minha mãe quando jovem e veio pra mim. Já tive pra descartá-lo porque ele tá com o espelho meio ruim, mas sabe como é que é e se para em silêncio. Mas ele é bastante usado, às vezes até minha nora vem pegar pra se maquiar porque ela disse que é bom pra pintar os olhos. Essa penteadeira e esse espelho a minha nora disse que é herança dela, que ela quer ficar com ela, não sei se até lá ainda vai querer.

Quando Eoní narra sobre o objeto como algo que vem sendo repassado através de gerações, está se referindo àquilo que é valioso e que precisa ser preservado, tal qual 
apontado nos estudos sobre memória e patrimônio por R. Abreu (2009). Nossa interlocutora nos conduz a refletir sobre os seus dilemas e indagações acerca de quem irá receber e dar continuidade ao cuidado com o objeto tido como patrimônio da família.

Lorena, por sua vez, tem uma penteadeira muito antiga. Ela adora deixar tudo organizado, com guardanapos bordados e os objetos dispostos sobre cada uma. Os pequenos objetos são guardados de forma metódica em cada gaveta, como ela nos descreve, ao longo de um percurso por sua casa:

Aqui em cima, essa imagem de Nossa Senhora Aparecida é especial porque eu trouxe de Aparecida mesmo, lá do santuário. As outras eu ganhei. Essa eu ganhei há uns quatro, cinco anos da Daniela (uma das filhas), e essa aqui eu ganhei nesse Natal da minha neta Manuela - e ela abre um porta joia - tem aqui um terço que veio do Papa, direto do Papa Francisco e este foi também a Manuela que trouxe pois teve lá visitando com o Joel. É isso, as minhas coisas. Este outro porta joias eu ganhei da minha amiga Rosina, que trouxe do Rio de Janeiro e esse outro aqui eu mesma comprei não lembro agora. Eu tenho terços e escapulários que eu compro ou ganho e gosto de pendurar, tinha um na cabeceira da cama que agora eu tirei e têm esses aqui. Ultimamente não tenho mais parado na frente da penteadeira assim, de sentar e ficar. Passo e coloco um batonzinho e é isso.

Lorena guarda os objetos recebidos de parentes e amigos ou mesmo os que compra e sabe da história de cada um. Embora esteja envolvida com uma série de atividades que a ocupam muito, ao ponto de não ter tempo de sentar diante de sua penteadeira, valoriza cada detalhe dos objetos que possui e que fazem parte de sua caminhada. Porém, chama atenção a questão da falta de tempo descrito por ela, sendo isso, talvez, uma estratégia ${ }^{8}$ a fim de superar alguns desconfortos em relação a solidão do cotidiano. Lorena está entre as mulheres que, conforme aponta Mary Del Priore (2013: 268-69),

Depois de décadas de dedicação ao marido, aos filhos e à família, descobrem-se sós. E felizes. Podem se dedicar aos projetos pessoais. Passam então a investir no próprio prazer. Vão estudar, viajar, caminhar. Tornam-se mais seguras, confiantes, autênticas. Perdem o medo de ser livres.

Ana, outra de nossas interlocutoras, possui três quartos em sua casa e em cada um, uma penteadeira. Em todas elas os principais objetos são ligados à espiritualidade como: imagens de santos, terços, escapulários e Bíblia. Enquanto mostra sua casa, conta: “Aqui é o quarto de visita, do meu filho quando eles vêm. Tem até o berço ali esperando quando eles chegarem”. Ela deixa os quartos rigorosamente limpos e organizados para os filhos com suas famílias, mesmo que a filha more no mesmo bairro

\footnotetext{
${ }^{8}$ Ver em Certeau, 1994: 97.
} 
que ela e que o filho venha de vez em quando. O espaço com suas imagens fotográficas e alguns de seus pertences dão a certeza da presença deles. Afinal “[...] a casa não vive somente no dia-a-dia, no curso de uma história, na narrativa de nossa história. Pelos sonhos, as diversas moradas de nossa vida se interpenetram e guardam os tesouros dos dias antigos” (Bachelard, 1993: 25). Em nossos percursos, ao deixar cada um dos ambientes da casa ela relembra como tais espaços eram antes do casamento dos filhos. De uma peça a outra, ao deslocar-se espacialmente, Ana viaja no tempo e passa a habitar os momentos felizes vividos em seu lar, sempre esperando o retorno deles para encher a casa e seu coração de alegria.

No caso de Celina, os “guardados” são as cartas de amor de seu esposo que the atestam, dia após dia, o sentimento que os unia e une ao longo de anos de casamento. “Tenho todas as cartas que o Clério escreveu pra mim. Ele sempre escrevia nas férias porque eu ficava o verão todo na praia com a minha patroa”.

A impressão dos afetos nos objetos de penteadeira e expressos nas narrativas de nossas parceiras de pesquisa, uma vez que sejam bem acondicionados nos jogos de suas memórias lhes permitem durar no tempo, afinal, como nos lembra Halbwachs (2003):

A história não é todo o passado e também não é tudo o que resta do passado. Ou, por assim dizer, ao lado de uma história escrita há uma história viva, que se perpetua ou se renova através do tempo, na qual se pode encontrar novamente um grande número dessas correntes antigas que desapareceram apenas em aparência (Halbwachs, 2003: 86).

Simples objetos que poderiam ser indiferentes à vida vivida por elas, transformam-se por esta via em objetos que fazem parte de seu patrimônio familiar. Por meio deles, e por sua condição de gênero no interior de suas famílias de origem e de procriação, nossas interlocutoras, em suas grande maioria, contam as histórias e percalços dos seus lares, possibilitando às novas gerações de filhos, sobrinhos e netos que deles se apropriarem, fatos, acontecimentos e personagens importantes para seu grupo de parentesco. Um processo de entrelaçamento entre tempos diversos, passado/presente/futuro, que nos lembra mais uma vez os comentários de G. Bachelard, (1993) sobre a poética dos gestos humanos que propagam a existência do ser na existência dos objetos e no mundo das coisas. Conforme nos lembra o autor:

[...] os objetos assim acariciados nascem realmente de uma luz íntima; chegam a um nível de realidade mais elevado que os objetos indiferentes, que os objetos definidos pela realidade geométrica. Propagam uma nova realidade de ser. Assumem não somente o seu lugar numa ordem, mas uma comunhão de ordem. Entre um objeto e 
outro, no aposento, os cuidados domésticos tecem vínculos que unem um passado muito antigo ao dia novo (Bachelard, 1993: 80).

Desta forma, tais objetos de penteadeira, na perspectiva do processo de envelhecimento dessas mulheres constituem, até certo ponto, “extensões morais de seus proprietários, e estes, por sua vez, são partes inseparáveis de totalidades sociais e cósmicas que transcendem sua condição de indivíduos” (Gonçalves apud Abreu, 2009: 27). Um processo de entrelaçamento entre os seres e as coisas cada vez mais denso, conforme a espessura do tempo vivido por cada uma de nossas parceiras de pesquisa.

Velhice: futuro de todos

Como pensar em envelhecimento estando inseridas nesse processo? Através das narrativas das parceiras de pesquisa pretendemos demonstrar a maneira como as protagonistas desse processo se enxergam nessa fase da vida e o que significa envelhecer para cada uma. Sobre o tecido complexo que trama os jogos da vida vivida e os jogos das memórias, e que são projetados nos objetos de penteadeira de nossas parceiras de pesquisa, nos inspiramos no que Halbwachs (2003) salienta a respeito dos laços que unem a memória individual com a memória coletiva e social, e das quais a primeira necessita para se projetar no tempo:

As condições necessárias para que umas e outras reapareçam não diferem senão pelo Grau de complexidade. Estas estão sempre a nosso alcance porque se conservam em grupos nos quais temos liberdade de entrar quando quisermos, nos pensamentos coletivos com os quais estamos sempre em estreito relacionamento, ainda que todos os seus elementos, todas as ligações entre esses elementos e as passagens mais diretas de uns aos outros nos sejam familiares (Halbwachs, 2003: 67).

Terezinha aponta que o envelhecimento têm aspectos positivos e negativos. Os positivos dizem respeito às escolhas. Conforme assinala, "posso escolher com quem e onde quero estar. Não preciso me relacionar com pessoas por simples obrigação”. Por outro lado ela entende que a parte negativa se dá em relação à disposição: “coragem eu tenho. Mas às vezes me sinto desanimada”. Esse aspecto é relacionado ao corpo, tanto físico quanto mental, principalmente porque ela afirma que fica meio deprimida em alguns momentos. 
Ela se envolve muito com os assuntos da família, estendendo isso à sobrinhos inclusive, visto que estes não têm mais os pais vivos e ela se sente responsável, por seu papel de gênero na sua família, pela promoção da harmonia e do equilíbrio no interior do grupo familiar, sendo todos residentes da mesma rua onde ela mora: "estas eleições me deixaram acabada. Tanta discussão em família. Estou muito triste com tudo isso. E torço para que tudo passe logo”.

Os laços de parentesco são extremamente importantes para ela visto que ela tem a família como "essência do passado" (Ferreira, 1998: 211). E, pode-se afirmar, de seu presente também. Da mesma forma pode-se perceber como os acontecimentos do espaço público refletem no privado: a política partidária interfere diretamente nas políticas de convivência, principalmente no seio familiar, pelo qual se torna, como mulher e anciã, responsável.

Numa outra perspectiva, temos Maria, que, segundo ela, vive o dia a dia sem parar para pensar sobre a velhice. Mas ela não tem medo do envelhecimento, muito pelo contrário. Ela quer superar todos os seus limites. Incrivelmente, Maria fala de si como “uma jovem mulher de 102 anos”. Ela se manifesta com muita alegria sobre os anos vividos e sobre as possibilidades que se apresentam em cada amanhecer. Organiza seus passeios, viagens, aniversários de parentes e amigos, todos lembrados rigorosamente.

O tempo de Maria é dividido entre essas atividades e muitas leituras. "Minha cabeça está sempre ocupada, nunca fico sem ter o que fazer”. Sua memória é excepcional. Um dos segredos seja, talvez, a quantidade de grupos distintos que ela frequenta. É um privilégio estar com ela porque sua energia e sabedoria são impressionantes: "eu gosto de declamar os versos que estudei nos anos de 1926 por aí”, e declama um para quem quiser ouvir. Dona Maria, como é carinhosamente chamada pela maioria das pessoas com quem convive, frequenta diversos espaços, como o Clube Cruzeiro, onde ajuda com palestras e sempre desfila no carnaval. Também vai a reuniões da Seicho-no-ie, ao salão de beleza e visitar amigos.

Bosi (1994: 60), ao tratar do velho, afirma que “ao lembrar o passado ele não está descansando, por um instante das lides cotidianas, não está se entregando fugitivamente às delícias do sonho: ele está se ocupando consciente e atentamente do próprio passado, da substância mesma da sua vida”. Dona Maria é um exemplo! Ela se ocupa alegremente de relembrar seu passado agora, durante sua velhice. Ela 
compreende que, ao narrar suas memórias, elas se mantêm vivas, acesas e, como fazem parte dela, ela mesma se reinventa e se torna ainda mais vibrante com este rememorar.

Marli, filha de Dona Maria, é o retrato de sua mãe: vê a velhice sempre com um sorriso no rosto. As duas juntas nos fazem pensar sobre as ponderações de $M$. Halbwachs acerca do que separa ou une as gerações no plano dos jogos da memória. Segundo o autor (2003: 90), “conforme a idade e também as circunstâncias, nos espantamos sobretudo com as diferenças e semelhanças entre as gerações que ora se fecham sobre si mesmas e se afastam uma da outra, ora se juntam e se confundem" (Halbwachs, 2003: 90). Marli e Maria são exatamente assim: um ir e vir entre as gerações, são camadas ora sobrepostas, ora justapostas. Num lindo movimento em que se percebe a relação do tempo e da duração, na prática da escuta etnográfica.

Todas as dificuldades enfrentadas por Marli durante sua trajetória pessoal e profissional a tornaram uma grande mulher. Com firmeza nas palavras ela descreve a si na velhice, com serenidade: “Tenho muitas metas em minha vida. Mas vou agindo conforme meu tempo, sem atropelar as coisas. Dou minhas palestras, passeio, visito e recebo amigos. Adoro receber meus amigos”.

Ela é um misto de resistência e afetividade. Tem clareza de suas possibilidades, tratando as pessoas sempre da mesma forma, com alteridade e paciência. "Mas eu também sei dizer não. Nem sempre é possível agradar a tudo. Devemos agradecer a Deus e à vida todos os dias. Isso sim”. Marli não fala sobre problemas de saúde nunca, assim como sua mãe. Uma das muitas heranças que recebeu de Dona Maria: “Quero seguir os passos de minha mãe. Quando ela está aqui em casa comigo é só alegria. Quero ser assim como ela”. O que se pode deduzir é que ela terá vida longa e saudável, como Dona Maria.

Sem mistérios, elas procuram viver o cotidiano com equilíbrio. "Tudo que é demais faz mal”, afirma Marli. E não é somente de alegrias que elas vivem. Não, inclusive suas lembranças trazem histórias que retratam a fome, a exclusão, a solidão. Mas nada disso tirou de Maria e Marli a alegria de viver. Muito antes, saboreiam agora cada pequena conquista, com extrema felicidade.

Bachelard (1993) aponta que "É preciso avançar na idade para conquistar a juventude, para livrá-la dos entraves, para viver segundo seu impulso inicial” (1993: 50). O que diz respeito ao modo como Marli vive o cotidiano de seu envelhecimento, 
exaltando a positividade e a espiritualidade que, segundo ela, a tornam mais ativa e feliz.

Ao nos determos nos testemunhos de Celina sobre o processo de envelhecimento, descobrimos algumas diferenças com as nossas outras parceiras de pesquisa. Ela traz em sua fala uma certa preocupação com o futuro: ela teve dois filhos, ambos falecidos: um ao nascer e a segunda depois de ter dado à luz à sua segunda neta. Suas netas moram com o pai e eles têm pouco contato. Celina se preocupa com seus guardados, pois acredita que ninguém terá interesse por eles:"Vê só, eu estou ficando velha e essas minha coisas ninguém vai querer. O que eu vou fazer com tudo isso?” Ela se refere ao patrimônio pessoal, seus objetos de valor sentimental, fruto de sua trajetória tão sofrida pela perda dos filhos. Ao mesmo tempo, em alguns momentos, sua narrativa demonstra desejos a realizar, estradas a percorrer. "Eu tenho coisas que quero conseguir, lugares pra ir e coisas pra ter. Mas cada coisa de uma vez”. Celina aponta para a necessidade de uma ordem, com um certo rigor inclusive. Pode-se refletir sobre suas perdas, seus traumas e as impossibilidades expressas por ela de construir novos encontros, de se colocar aberta a conhecer pessoas, descobrir lugares e reinventar o seu cotidiano.

Para ela, a velhice se aproxima de uma forma muito rápida. Então, necessita de ocupação para que não esteja esperando o desânimo, a lentidão e a falta de elasticidade chegar. Celina sempre foi muito ativa corporalmente: "Eu preciso achar um serviço voluntário, qualquer um. Preciso ajudar as pessoas, me envolver com as histórias deles, isso. Num asilo, numa creche, não sei. Mas preciso”.

Para o caso da condição de gênero que delimita o universo pesquisado observamos o que Ferreira (1998: 216) aponta em seus estudos, ou seja, uma "estreita ligação entre o espaço familiar e o sujeito manifesta-se com intensidade à medida que, com o avanço em idade, vão-se esvaecendo os registros desses tempos vividos, num somatório crescente de perdas”. Aqui, a narrativa biográfica de Celina é um caso exemplar entre as outras. Ela tem necessidade de se ocupar para, talvez, deixar num espaço recôndito a quantidade de perdas que teve em sua trajetória. E assim, com as lembranças dessas dores escondidas em um recanto profundo, ela possa ressignificar seu momento atual, favorecer seu reencantamento pela vida, pelas pessoas e por si mesma.

O reforço dos laços que unem essas mulheres aos seus lares aparece de outra forma na biografia de Ana. Ela adora se ocupar das coisas do lar, ajudar filhos e netos, 
mas os problemas com a saúde é que remetem as suas perdas. Além disso, só se envolve com as atividades da igreja: "Não posso ficar indo em baile ou outras atividades porque minha coluna não deixa. Com minha clavícula incomodando desde o início do ano, não posso esticar meus braços”. Para ela, a velhice vai trazendo dores e problemas de saúde: “Não posso mais fazer de tudo na casa. Daí me ocupo fazendo tricô e crochê”.

A casa de Ana parece uma casinha de brinquedo, com detalhes na decoração de cada canto, com os quartos arrumados esperando a visita dos filhos. Ela mora com o esposo e passa os dias a organizar a casa. As pessoas com as quais mantém relacionamento são os parentes mais próximos e os vizinhos. Isso se justifique, talvez, em função dos momentos vividos na infância, onde sua família mudou-se inúmeras vezes, sempre com o medo de não ter onde ficar. Ana, em sua velhice, busca em seu lar extremamente organizado, o recanto de sua infância marcada pela insegurança. A presença marcante do lar como referência de identidade em seu processo de envelhecimento é marcante, o que nos faz lembrar dos comentários de G. Bachelard (1993) sobre a morada, a casa natal, como centro do universo de nossos devaneios, e que, para nós, aparece de forma mais aguda no processo de envelhecimento de nossas parceiras de pesquisa. Conforme aponta o autor:

Mais que um centro de moradia, a casa natal é um centro de sonhos. Cada um de seus redutos foi o abrigo de devaneio. E o abrigo não raro particularizou o devaneio. Foi aí que adquirimos hábitos de devaneio particular. A casa, o quarto, o sótão onde ficamos sozinhos dão os quadros de um devaneio interminável, de um devaneio que só a poesia, em uma obra, poderia concluir, realizar (Bachelard, 1993: 34).

A presença de antigas amizades e da cumplicidade com elas é outro ponto de convergência das falas de algumas de nossas interlocutoras. Eoní se manifesta com muita tranquilidade sobre o processo de envelhecimento desde esta ótica: "Eu adoro usar meu tempo de aposentada para encontrar minhas amigas, ler e viajar. Participo de grupos com atividades diversas e estou sempre pronta quando o Bruno quer sair”. Ela mostra seus objetos guardados que retratam essas experiências, com muita satisfação. Eoní diz que fazem parte de sua história porque revelam os lugares por onde andou e as pessoas com quem esteve. Seus objetos não falam, mas ela os compreende, uma vez que tais objetos de penteadeira, como aponta Halbwachs (2003:158), detêm um sentido que "familiarmente deciframos”; assim, "são imóveis somente na aparência, pois as preferências e hábitos sociais se transformam e, quando nos cansamos de um móvel ou de um quarto, é como se os próprios objetos envelhecessem”. 
Como Celina, as limitações corporais pontuam suas falas sobre o processo de envelhecimento. "Minha velhice vou vivendo com serenidade. Sei das minhas limitações e então cuido do meu corpo e da minha mente”, conta Eoní. Por isso ela toma os devidos cuidados com sua saúde. Ela gosta de ler livros e fazer anotações. Esse costume possivelmente vem do tempo em que era bibliotecária na maior escola municipal de Portão/RS: “Os livros são como meus amigos. Estão por perto sempre que preciso. Se não viajo pelas estradas, viajo com os livros”. Então ela mostra alguns de seus livros e vai resenhando os que toca com as mãos. "Mesmo com alguma dificuldade pra caminhar por causa de uma perna mais curta, nunco deixo de fazer caminhadas, seja na praia ou aqui no bairro. É um prazer pra mim, assim como cuidar das minhas flores”. O jardim de Eoní é impecável: produz flores o ano todo pois ela plantou qualidades diversas a fim de que sempre tivesse cor e perfume no entorno da casa.

Estudos na área de Gerontologia apontados por Guita Debert (1994: 41) dão conta de características positivas no envelhecimento, entre elas a que afirma que "a terceira idade é o momento de melhor avaliação crítica da vida em virtude das experiências acumuladas. A pessoa torna-se mais detalhista e mais paciente”. Estas características são facilmente percebidas na fala de Eoní.

Da mesma forma, transparecem nas falas de Valéria que, diante de seus objetos de penteadeira, conta detalhes dos momentos vividos, especialmente quando fala de seus pais, das angústias sentidas em um colégio interno, da força da religiosidade e do tempo em que esteve internada por motivo de depressão. "Sabe, eu tenho guardado comigo o terço que minha mãe me deu quando eu estava internada. Ele está arrebentado e eu guardo ele exatamente assim para nunca esquecer da fé que me ajudou a superar a depressão”. Simmel (1983: 127), quando trata sobre o conflito afirma que esse "não é só um meio de preservar a relação, mas uma das funções concretas que verdadeiramente a constituem”. Os conflitos apresentados por Valéria, no colégio interno, com sua mãe, seu pai, seu primeiro esposo e consigo mesma durante suas crises de depressão, representam essa relação propriamente dita. Para ela, todos os momentos de solidão e de incertezas foram recompensados quando conseguiu adotar sua filha: “A Cecília é a riqueza da minha vida, minha alegria”. Atualmente Valéria ainda se medica, mas crê que a fase do envelhecimento é o momento em que se sente mais fortalecida. “Agora eu consigo compreender as coisas que passei. Tudo tem um motivo. Eu me sinto muito melhor hoje”. Ela diz que pode sair a hora que quiser, quando o marido avisa que vai 
fazer uma viagem, ela vai junto. Também participa de grupos onde desenvolvem artesanato como pintura e bordado.

Chegamos, agora, a Lorena, uma das nossas parceiras de pesquisa que procura viver de forma ativa e ludica o seu processo de envelhecimento, participando de atividades em grupos diversos, liderando atividades do Clube de Mães do município de Portão, do grupo de bolão, ajudando uma de suas filhas em eventos vendendo artesanato, entre outras coisas. "Eu adoro estar no meio das pessoas, sentar e conversar, realizar brincadeiras. Nos passeios que faço procuro conhecer a história e as pessoas de cada lugar. Procuro estar sempre de bem com a vida, mesmo quando não estou bem”.

Trata-se de uma pessoa intensa na forma como explora as diversas dimensões de sua condição de gênero da família, fazendo delas um processo de empoderamento de si na velhice. Nestes termos, ela reinventa o seu clássico papel de gênero na família e faz da "equação mulher-trabalho-maternidade-família” a sua força, ou nos termos empregados por Fávaro (2002: 26) faz de sua condição subalterna "um centro de poder".

Ela viaja bastante e sempre incentiva as pessoas a fazerem o mesmo. É independente, vive sozinha com seus quase 80 anos. "Eu me divirto muito na internet, estou sempre procurando estar à frente de meu tempo. Tem gente que pára no mundo e ele dá voltas. É preciso estar sempre girando com ele” - e dá risada. Lorena contagia as pessoas que estão a sua volta. "Tive muita dificuldade na vida e hoje estou plena. Me sinto livre. Às vezes fico olhando os casais de idosos de mãos dadas e penso que poderia estar assim também. Mas tem gente que pensa diferente, paciência”. Ela se divorciou há menos de uma década e ainda não assimilou totalmente isso. Até nesse quesito pode-se sentir uma mulher vibrante, intensa e que deseja amar e ser amada. $\mathrm{O}$ desejo de que as coisas estejam em seus devidos lugares lhe é alcançado através do relembrar de suas memórias. Em Lorena, conforme pontua Bosi (1994: 452) “à resistência muda das coisas, à teimosia das pedras, une-se a rebeldia da memória que as repõe em seu lugar antigo". Acreditamos que isso lhe encoraja a se maquiar todos os dias, a usar sua melhor roupa em todos os momentos, ao se presentear com passeios e festas. Esse é o modo encontrado por Lorena para organizar as pedras de seu caminho. 
Conclusão

O período de vida atual dessas mulheres, em seu processo de envelhecimento, narrado diante de seus objetos, traz a importância da independência, muito mais do que o apego às perdas, derrotas e problemas enfrentados durante o percurso. Obviamente que, para algumas delas esses momentos trágicos estão muito presentes agora na velhice, mas, de qualquer sorte, mostram coragem para enfrentá-los, mesmo que nas lembranças presentes em seu cotidiano.

A necessidade de autonomia parece ser mais relevante do que se refletir sobre a solidão. Ainda mais quando se percebe uma intensa participação em grupos distintos, onde a sociabilidade é fator preponderante nas relações, afinal a velhice é um constructo social e precisa estar notadamente presente nesse espaço contemporâneo. O idoso, neste caso, as idosas, fazem parte dessa sociedade e, para além de brincadeiras e jogos, querem marcar sua posição, opinião e construir este novo espaço, o da velhice na sociedade urbana, afinal, segundo ressalta Halbwachs (2003):

Como uma sociedade, qualquer que seja ela, poderia existir, subsistir, tomar consciência de si mesma, se não abrangesse com um olhar um conjunto de acontecimentos presentes e passados, se não tivesse a faculdade de retroceder no fluxo do tempo e repassar ininterruptamente os vestígios que deixou de si mesma? (Halbwachs, 2003: 155).

As cidades de Portão e Novo Hamburgo são o espaço onde “as correntes opostas" que encerram a vida de nossas interlocutoras de pesquisa "se desdobram" (Simmel, 1973: 25-26). É nesse lugar, na região metropolitana de Porto Alegre, no Vale do Sinos, que essas mulheres circulam, se deslocam e constroem as suas narrativas.

É possível perceber nos relatos das mulheres em processo de envelhecimento o quão é especial cada espaço vivido na cidade. Mesmo que já tenha se transformado no concreto, em suas memórias permanece vivo como anteriormente: espaço diverso e complexo, assim como toda sociedade e, em especial, as pessoas que experimentam a velhice na contemporaneidade. Sob esse ângulo, torna-se evidente em todos os relatos que, na evocação da vida objetiva sobre o ato de envelhecer numa grande metrópole contemporânea, "a cidade é convocada, nos relatos dos idosos, como arranjo poético de suas vidas vividas” (Eckert e Rocha, 2010: 131). E foi no ato de adentrar à complexidade e diversidade dos arranjos poéticos que os objetos de penteadeira provocam nas memórias de nossas parceiras de pesquisa que residiu a beleza do nosso 
encontro etnográfico com elas, e onde, inúmeras vezes, se podia perceber nos relatos sobre o envelhecimento "a tensão entre individualização e a busca de sociabilidade" (Velho, 1986: 77) no âmbito do seus arranjos sociais.

Priore (2000) aponta que, as pessoas em geral querem viver mais, porém, não querem envelhecer. Portanto, o envelhecimento não pode ser visto como uma ameaça à vida social devido aos problemas trazidos pela necessidade de se criar suporte para este grupo específico. Além disso, conforme assinala G. Debert (1998: 65) a transformação do envelhecimento em objeto de saber científico “põe em jogo múltiplas dimensões: do desgaste fisiológico e do prolongamento da vida ao desequilíbrio demográfico e ao custo financeiro das políticas sociais".

A criação de diversos grupos, inclusive pelas próprias protagonistas das histórias aqui narradas, tem se demonstrado bastante eficiente para a manutenção da saúde, da sociabilidade e das trocas e múltiplos saberes que acompanham essa fase de suas vidas. As atividades propostas através dos grupos ligados ao poder público ou iniciativa privada como o Sesc Maturidade Ativa ${ }^{9}$, por exemplo, citado por elas, propiciam momentos de socialização e saúde para todas. Da mesma forma, transparece nas suas falas que a aposentadoria deixa de ser um tempo de recolhimento para ser sinônimo de lazer e, para tanto, “já não se trata de resolver os problemas econômicos dos idosos, mas também proporcionar-lhes cuidados culturais e psicológicos, de forma a integrar socialmente uma população tida como marginalizada” (Debert, 1999: 61).

O envelhecimento está permeado, na contemporaneidade, pela ressignificação. Envelhecer é ter tido a oportunidade de acumular experiências. Estas experiências, por sua vez, necessitam ser relembradas para haja a possibilidade de se criar uma nova rede de significados.

Através das narrativas coletadas durante a etnografia percebeu-se que as similitudes entre elas dizem respeito a vários aspectos, tais como: a atenção dispensada ao tema dos filhos, do casamento, da família, dos objetos legados por seus antepassados. A condição feminina de centralizar as histórias das famílias a partir de objetos que remetem aos fragmentos de parte de suas heranças, e que por isto mesmo, tem razão para recomeçar nas futuras gerações que vão sucede-las.

\footnotetext{
${ }^{9}$ Programa desenvolvido pelo Serviço Social do Comércio, ligado à Fecomércio RS (Rio Grande do Sul) que desenvolve uma série de atividades artísticas, recreativas, culturais e esportivas, para promover o protagonismo e a participação ativa de idosos.
} 
Ao sentarem diante de suas penteadeiras, essas mulheres trouxeram também a força do feminino, para além dos cuidados com os objetos e envolvimento com trabalhos manuais que elas realizam com empenho, mas como se situam na sociedade. Apesar de serem de um modo ou de outro, ligadas à religiosidade, o que de certa forma, provoca pressões em muitos âmbitos, elas não se submeteram a todo tipo de norma e sairam em busca de realização profissional em períodos que isso era dificultado. Assim, nesse deslocamento do estritamente privado para o público, encontraram alternativas para se colocarem no mundo, com suas ideias e posicionamentos, realizando sonhos e possibilitando ‘aberturas’ para as gerações seguintes.

As diferenças apresentadas por meio de suas rememorações tratam, especificamente, da maneira como cada uma enfrenta as circunstâncias ocorridas no trajeto pessoal, como os problemas de saúde do corpo que envelhece e as perdas de pessoas de seus vínculos familiares e de afeto. Algumas têm maior flexibilidade e entendimento de como os fatos se sucedem e, por isso, ocupam o tempo de maneiras múltiplas, entre leituras, viagens e encontros com grupos diversos.

Investigar as memórias de pessoas em processo de envelhecimento a partir de seus objetos de recordação é buscar vestígios que constituem a identidade delas e refletir sobre o que isso diz respeito a cada um de nós, pesquisadores. Isto porque o etnógrafo também se constrói, para além de pesquisador, como indivíduo ao se imbricar em cada história rememorada. Ouvir, escrever e ler, empregando as palavras de J. G. Magnani (2009), as narrativas aqui apresentadas tem, assim, claramente uma função social, a de construção de sentido no ritual cotidiano de uma pessoa ao chegar na velhice. A fala das mulheres em processo de envelhecimento 'toca e fala' por e para quem investiga.

Durante o trabalho etnográfico foi possível perceber "que a atividade a que as informantes se dedicavam concretizava um projeto, ou melhor, o último projeto passível de ser realizado até o fim da vida” (Barros, 1998: 121). E neste ponto também se apresenta o que há de arte na etnografia com observação participante: sensibilidade, escuta, a atenção aos códigos, cores, sons, aos silêncios, sendo observador e, ao mesmo tempo, observado (Velho e Viveiros de Castro, 1978). É pensar na velhice delas, na dos outros, na nossa. É pura arte.

Ao final da investigação, refletindo sobre o móvel penteadeira, seus deslocamentos e alterações ao longo do tempo, as questões da velhice, do processo de 
envelhecimento e do corpo, é possível pensar sobre o modo como este símbolo de introspecção, veneração solitária ou contemplação narcísica, pode ser mediador de acesso às memórias, como facilitador da organização de ideias e da compreensão de momentos da trajetória de vida, especialmente ao pensarmos no espelho que é parte integrante desse. Para além da superfície, da estética do feminino, espelha com profundidade as transformações e os jogos das memórias, testemunhando a passagem do tempo. O que o espelho da penteadeira revela do corpo que envelhece é a sua condição de ser o reservatório de lembranças e histórias vividas.

Referências

ABREU, Regina. CHAGAS, Mário. Memória e patrimônio: ensaios contemporâneos. Regina Abreu, Mário Chagas (Orgs.). - 2ª ed. - Rio de Janeiro: Lamparina, 2009.

BACHELARD, Gaston. A poética do espaço. São Paulo: Martins Fontes, 1993.

BARROS, Myriam M. L. Velhice ou terceira idade? Estudos antropológicos sobre identidade, memória e política. Org. Myriam M. L. Barros. - Rio de Janeiro: Editora Fundação Getúlio Vargas, 1998.

BASSIT, Ana Z. História de Mulheres: reflexões sobre a maturidade e a velhice. In: MINAYO, M. C. S., COIMBRA JUNIOR, C. E. A. (Orgs.). Antropologia, saúde e envelhecimento. - Rio de Janeiro: Editora Fiocruz, 2002.

BOSI, Ecléa. Memória e Sociedade: lembranças de velhos. - 3. ed. - São Paulo: Companhia das Letras, 1994.

BRANCO, Ana C. História das penteadeiras: saiba mais sobre essa peça! Disponível em: http://blog.lilibee.com.br/historia-das-penteadeiras/ Acesso em 27/12/2017.

CARVALHO, Vânia C. Gênero e Artefato: O Sistema Doméstico na Perspectiva da Cultura Material. - São Paulo: Editora da Universidade de São Paulo/Fapesp, 2008.

CERTEAU, Michel de. A invenção do cotidiano: 1. artes de fazer / Michel de Certeau; tradução de Ephraim F. Alves. - Petrópolis, Vozes, 1994.

COLLING, Sandra M. C. P. As amigas de minha mãe: uma relação entre o objeto de pesquisa, artistas brasileiras e mulheres da ficção. In: II Cidi - Congresso Internacional de Diálogos Interdisciplinares: desafios para o desenvolvimento individual e coletivo dos sujeitos nas sociedades contemporâneas. Anais... Novo Hamburgo: Universidade Feevale, 2018. v. 2. p. 1069-1076. 2018.

DEBERT, Guita G. A antropologia e o estudo dos grupos e das categorias de idade. In: BARROS, Myriam M. L. (Org.) Velhice ou terceira idade? Estudos antropológicos 
sobre identidade, memória e política. - Rio de Janeiro: Editora Fundação Getúlio Vargas, 1998.

A reinvenção da velhice: socialização e processos de reprivatização do envelhecimento. São Paulo: Editora da Universidade de São Paulo, FAPESP, 1999.

Gênero e envelhecimento. Estudos feministas, v. 2, $\mathrm{n}^{\circ}$ 3. Florianópolis: Revista Estudos Feministas, UFSC, 1994.

ECKERT, Cornelia; ROCHA, Ana L. C. Cidade narrada, tempo vivido: estudos de etnografias da duração. Revista Rua, Laboratório de Estudos Urbanos, Campinas, n. 16, vol. 1, junho 2010.

FÁVARO, Cleci E. Imagens femininas: contradições, ambivalências, violências. Porto Alegre: EDIPUCRS, 2002.

FERREIRA, Maria L. M. Memória e velhice: do lugar da lembrança. In: BARROS, Myriam M. L. (Org.). Velhice ou terceira idade? Estudos antropológicos sobre identidade, memória e política. - Rio de Janeiro: Editora Fundação Getúlio Vargas, 1998.

FISCHER, Ernest. A necessidade da arte. Tradução Leandro Konder. Rio de Janeiro: Zahar Editores, 1983.

FOOTE-WHYTE, William. Treinando a observação participante. Trad. Cláudia Menezes. In: GUIMARÃES, Alba Z. (Org.). Desvendando Máscaras Sociais. - Rio de Janeiro: Livraria Francisco Alves Editora S.A., 1975.

GONÇALVES, José R. S. Antropologia dos objetos: coleções, museus e patrimônios. In: GONÇALVES, José R. S. (Org.). Coleção Museu, Memória e Cidadania. Rio de Janeiro: Editora Garamond, 2007.

HALBWACHS, Maurice. A memória coletiva / Maurice Halbwachs; Tradução de Beatriz Sidou. São Paulo: Centauro, 2003.

IBGE - Instituto Brasileiro de Geografia e Estatística. In: https://cidades.ibge.gov.br/ MAGNANI, José G. C. Etnografia como prática e experiência. Horizontes Antropológicos, Porto Alegre, ano 15, n. 32, p. 129-156, jul./dez. 2009.

PRIORE, Mary D. Conversas e histórias de mulher. - 1ª ed. - São Paulo: Planeta, 2013. Corpo a corpo com a mulher: pequena história das transformações do corpo feminino no Brasil. São Paulo: Editora Senac, 2000.

SIMMEL, Georg. A metrópole e a vida mental. In: VELHO, Otávio. (Org.). O Fenômeno Urbano. Rio de Janeiro: Zahar Editores, 1973.

A natureza sociológica do conflito. In: MORAES FILHO, Evaristo de. (Org.) Simmel - Sociologia. Coleção Grandes Cientistas Sociais, vol. 34. São Paulo: Ática, 1983. 
VELHO, Gilberto e VIVEIROS DE CASTRO, Eduardo B. O Conceito de Cultura e o Estudo das Sociedades Complexas: uma perspectiva antropológica. Artefato Jornal de Cultura. Rio de Janeiro: Conselho Estadual de Cultura, n. 1, Jan., 1978.

VELHO, Gilberto. Observando o Familiar. In: NUNES, Edson de Oliveira. A Aventura Sociológica. Rio de Janeiro: Zahar, 1978.

1986.

. Subjetividade e sociedade: uma experiência de geração. Rio de Janeiro: Zahar,

Recebido 23/04/2019

Aprovado 28/05/2019 